\title{
Development of technological schemes for open-pit mining of deposits using "mobile crushing-reloading-conveyor complexes"
}

\author{
Tulkin Annakulov ${ }^{1 *}$ \\ ${ }^{1}$ Tashkent State Technical University, Department of Mining Electromechanics, 2 University St., \\ 100095 Tashkent, Republic Uzbekistan
}

\begin{abstract}
This article analyses the use of cyclic-flow technology schemes with mobile crushing and reloading complexes in open cast mining. An analysis of the application of cyclic-flow technology schemes with mobile crushing and reloading complexes in open cast mining shows that the main directions of its radical improvement are the development, creation and implementation of fundamentally new mining transport equipment and technological schemes for its quarries, which include: "mobile excavators crushing and transhipment plants and conveyor systems". Technological schemes for the development of rocks with an end arrangement of mobile complexes using a single bucket excavator and conveyor transport, with an end arrangement of mobile complexes and an increased width of the working platform during conveyor transport, with an end arrangement of mobile complexes and the presence of a mobile interstage loading crane with sequential mining at three horizons, a methodology has been developed for determining the working time and annual productivity of mobile crushing and handling conveyor complexes and a new technological scheme for the development of overburden ledges using mobile crushing and handling conveyor complexes. To reduce the time for idling the complex and reduce the number of exit ledges, a new technological scheme for the development of overburden ledges with the use of mobile complexes is recommended. As a result of the calculations according to the developed method, when working out two benches with different block lengths, the dependence of the annual productivity of the complex on the block length was established.
\end{abstract}

\section{Introduction}

In the open-pit mining of carbonate rock deposits of uniform strength and diverse strengths with a content of weak differences of up to $30 \%$ in complexes with mobile equipment, mobile crushing plants, mobile interstage conveyor reloader and mobile downhole conveyors are used $[1,2]$.

There are 3 main schemes for organizing mining operations in the development of sedimentary, carbonate and rock, which differ in the type of machinery and installations

\footnotetext{
* Corresponding author: a.tulkin1275@yandex.ru
} 
used, as well as their location in the face $[1-6]$ :

1) with the installation of a mobile crusher in the face (Fig. 1,a) in which the rock is loaded into the crusher by an excavator through a hopper feeder, which is an integral part of the crusher and mounted on the same platform with it. Crushed rock downhole conveyor is transported directly to the intermediate or main conveyor. The main disadvantages of this scheme are the need for fencing downhole conveyors during blasting and their frequent movement;

2) with the installation of a mobile conveyor-reloader or interstage conveyor-reloader between a mobile crusher and a downhole conveyor (Fig. 1, $b$ ). The rock is loaded into the crusher by an excavator through a hopper feeder. The rock from the crushing plant is transferred to a mobile conveyor-reloader and further to the downhole conveyor. Using a mobile conveyor reloader allows you to reduce the frequent movement of the downhole conveyor and place them at a great distance from the bottom;

3) using mobile crushers at the working site (Fig. 1,c). The extraction, loading and delivery of the rock mass to the crushers is carried out by single-bucket wheel loaders. With this scheme, the movement of the crusher and conveyor is less frequent compared to the first and second schemes. The distance of delivery of the rock mass from the bottom with a single-bucket loader determines the movement step. This scheme is often used in the development of building rocks.

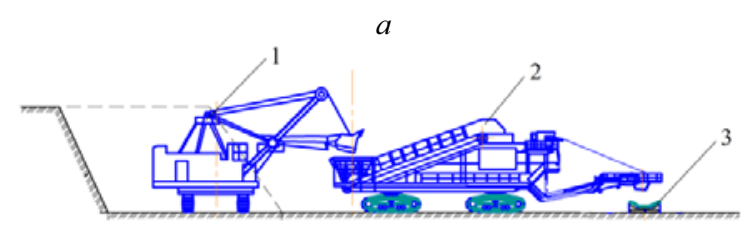

$b$

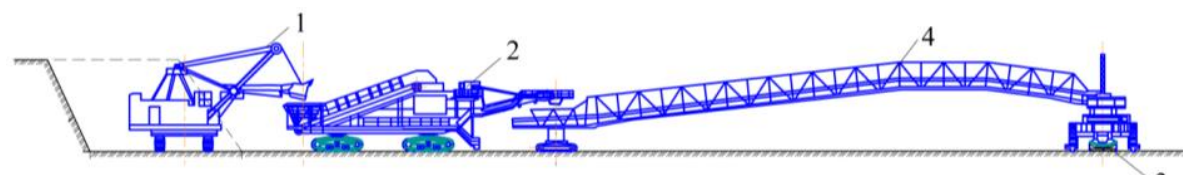

3

$c$

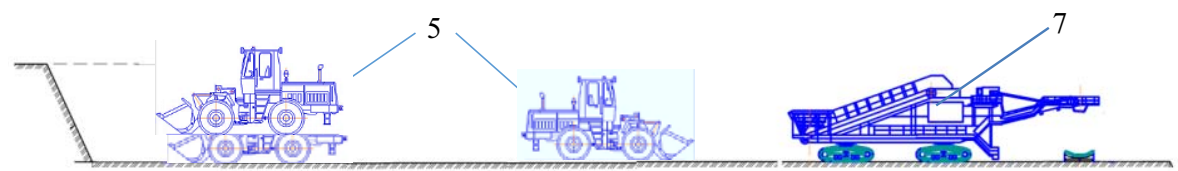

Fig. 1. Schemes of development of rock using conveyor transport: 1 - excavator; 2 - mobile crushing plant; 3 - downhole conveyor belt; 4 - mobile conveyor reloader; 5 - single bucket loaders; 7 mobile or mobile crushing plant.

In the scientific literature, only the basic methods for developing deposits using mobile crushing complexes are given, in connection with this there is a need to find an effective technological scheme for their application. The rationality and effectiveness of the application of technological schemes using "mobile crushing-reloading-conveyor complexes" (MCRCC) depend on the specific geological and mining conditions. Also, when using mobile crushing complexes, it is necessary to predict the efficiency of mining operations, and also take into account the reliability of the equipment complex and the environmental consequences of operating crushing plants in the quarry. In this regard, when making decisions on the use of mobile crushing complexes, it is necessary to scientifically substantiate and systematize the mining schemes. 


\section{Methods}

When choosing the optimal technological scheme for overburden mining using MCRCC is necessary $[4-6]$ :

1. Choose a type of crushing plant that would ensure the maximum productivity of the excavator and the required lumpiness of rocks with various physical and mechanical properties.

2. Select the optimal mining and handling equipment taking into account the required technological parameters, such as, for example, discharge height, excavator bucket capacity, its productivity, method of loading into the crusher hopper, etc.

3. Take into account the presence and type of reloaders (horizontal or interstage).

3. Choose the type of downhole conveyor (mobile or telescopic).

4. Choose the installation method of the crushing plant during the loading, followed by the excavator and parallel to the bottom of the face.

5. Choose installation methods and moving the interstep loading crane.

The use of MCRCC is most appropriate when working out benches with longitudinal approaches. In this case, it is possible to practice the ledges from one position of the face conveyor in narrow (for one excavator approach) or wide (up to two to three excavator approach) strips.

\section{Results and discussion}

Consider various significant options for the application of technological schemes using MCRCC.

1-option. The technological scheme of the development of rocks with the end position of the MCRCC using a single-bucket excavator and conveyor transport. This technological scheme is used when mining long blocks or small open cast mine with no blasting development of semi-overburden rocks (Fig. 1,a) [2,7].

2-option. The technological scheme of the development of rocks with the end position of the MCRCC and the increased width of the working platform with conveyor transport (Fig. 1,b) [2, 6].

The number of movements of the downhole conveyor is reduced by introducing into the technological scheme a telescopic mobile conveyor or a mobile belt and interstage conveyor reloader. Their sufficient length allows the downhole conveyor to be installed outside the danger zone during blasting operations.

Installation of a mobile conveyor reloader ensures a safe distance to the downhole conveyor and reduces the cost of moving the conveyor stand.

3-option. Technological scheme of working out benches by longitudinal approaches by the MCRCC complex with a lateral location of the downhole conveyor and the presence of a mobile interstart-reloader with sequential mining operations at 3 horizons (Fig. 2)

According to this technological scheme, the downhole conveyor is initially installed on the second ledge (between the first and third ledges). MCRCC sequentially fulfills the first step (Fig. 1, $a$ ), then the third (Fig. 1, b) and at the end of the second step (Fig. 2, c). After that, the downhole conveyor frontally moves along the width of the excavator's entry [7].

The working time of the complex during the development of one block (cycle) is:

$$
T_{C Y C L E}^{1}=\frac{V_{B L O C K}}{Q_{\text {oper }}^{h} K_{p}}=\frac{B_{W} L_{B} H_{L}}{Q_{O . P .} K_{p}},
$$

where $Q^{h}{ }_{\text {oper }}$ is the operational productivity of the complex, $\mathrm{m}^{3} / \mathrm{h} ; K_{p}$ is coefficient of productivity reduction, taking into account the shutdown of the complex, technological and 
organizational factors $\left(K_{p}=0.85-0.95\right) ; V_{B L O C K}$ is the volume of the processed block, $\mathrm{m}^{3}$; $B_{W}$ is excavation trench width, $\mathrm{m} ; L_{B}$ is block length, $\mathrm{m} ; H_{L}$ is ledge height, $\mathrm{m}$.

$a$

Bench-1, Horizon -15.0 m

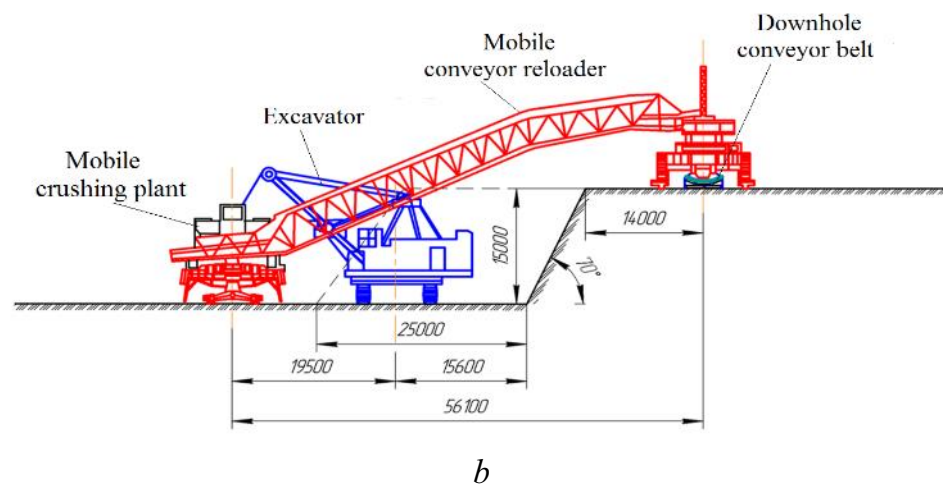

Bench-3, Horizon $+15.0 \mathrm{~m}$

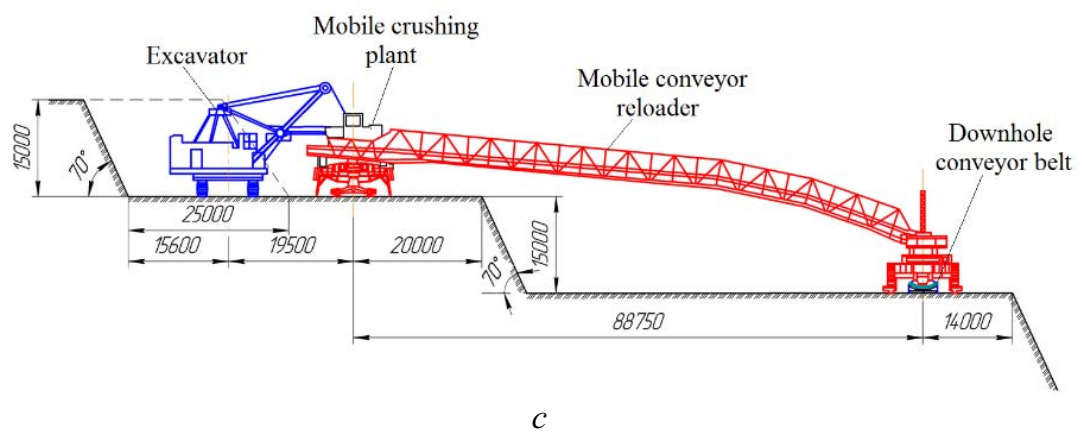

Bench-2, Horizon $+0,0 \mathrm{~m}$

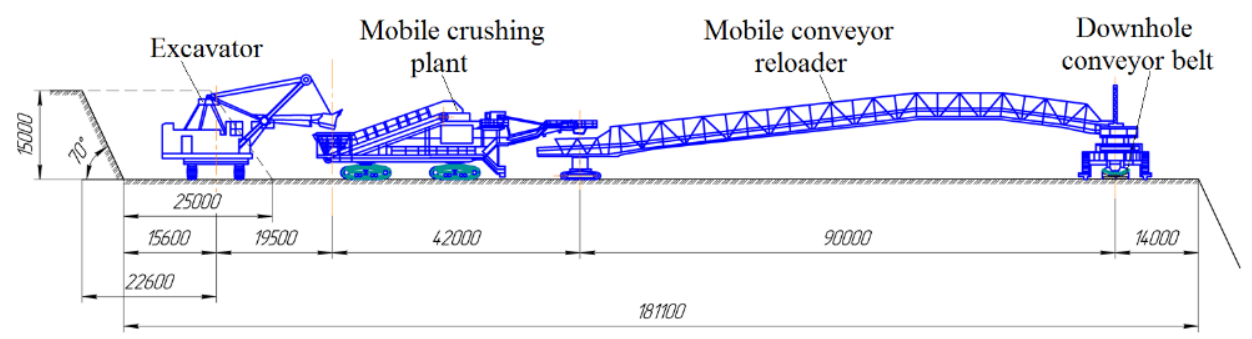

Fig. 2. The technological scheme of working out the benches with longitudinal runs by the MCRCC complex with a lateral location of the downhole conveyor and the presence of a mobile interstage loading crane with sequential mining operations at 3 horizons: $a$ - the complex operates on a 1 ledge; $b$ - the operation of the complex on a 3 -step; $c$ - operation of the complex on a 2 -step.

The time of movement of the downhole conveyor is determined by the formula [8]:

$$
T_{\text {D.S.M. }}=t_{p}+\frac{B_{W} L_{d} K_{i}}{K_{S}^{t} P_{T}}+t_{f}, \mathrm{~h},
$$


where $t_{p}$ is the time for preliminary and auxiliary operations when moving the conveyor stand ( $t_{p}=3 \mathrm{~h}$ according to [8]); $L_{d}$ is the length of the stav downhole conveyor, m; $K_{i}$ is coefficient taking into account the influence of production conditions on the implementation of the movement process $\left(K_{i}=1.2\right.$ according to [8]); $K_{s}^{t}$ is coefficient of use of the tournode doser during the shift $\left(K_{s}^{t}=0.56\right.$ according to [3]); $t_{f}$ is time for final operations when moving the conveyor bed ( $t_{f}=4$ hours according to [8]); $P_{T}$ is technical productivity of the tournode doser:

$$
P_{T}=v_{T}+B_{T}, \mathrm{~m}^{2} / \mathrm{h}
$$

where $v_{T}$ is operating speed of a tournode doser, $\mathrm{m} / \mathrm{h} ; B_{T}$ is step width of the stroke of the tournode doser, $\mathrm{m}$.

The annual operating time of the complex, taking into account the working time of the excavator, is determined by the formula:

$$
T_{A}=T_{S H} n_{S H} N_{W} K_{U},
$$

where $T_{S H}$ is the duration of the shift, $\mathrm{h} ; n_{S H}$ is the number of shifts per day; $N_{w}$ is the number of working days of the excavator per year; $K_{U}$ is utilization factor of the complex change time (is $K_{B}=0.73-0.85$ ).

The number of cycles performed in the developed blocks of the complex per year is determined by the formula:

$$
N_{C U C L E}^{1}=\frac{T_{A}}{N_{C U C L E}^{1}+T_{m . d . k} .} .
$$

The annual productivity of the complex is determined by the formula:

$$
Q_{C O M}^{A}=V_{B L O C K} \cdot N_{C Y C L E}^{1}=B_{W} L_{B} H_{L} \cdot N_{C Y C L E}^{1}, \mathrm{~m}^{3} / \text { year. }
$$

Table 1 shows the results of calculations of the annual productivity of the MCRCC complex at different block lengths according to the 1st option of the technological scheme.

Table 1. Calculation results of the MCRCC complex during the development of benches according to the technological scheme for the development of rocks with the end face of the equipment using a bucket excavator and conveyor transport.

\begin{tabular}{|c|c|c|c|c|c|c|c|}
\hline $\begin{array}{c}Q^{4} \text { COM, } \\
\mathrm{m}^{3} / \text { year }\end{array}$ & $\begin{array}{c}Q_{\text {oper, }}^{h} \\
\mathrm{~m}^{3} / \mathrm{h}\end{array}$ & $\begin{array}{c}V_{\text {BLOCK, }} \\
\mathrm{m}^{3}\end{array}$ & $\begin{array}{c}T_{\text {CYCLE }}, \\
\mathrm{h}\end{array}$ & $\begin{array}{c}L_{B L O C K} \\
\mathrm{~m}\end{array}$ & T..S.M., $\mathrm{h}$ & $T_{A}, \mathrm{~h}$ & $N^{1}{ }_{\text {CYCLE }}$ \\
\hline 4767252.6 & 1478 & 53400 & 40.14 & 200 & 19.71 & 5344 & 89.3 \\
\hline 4960630.4 & 1478 & 80100 & 60.21 & 300 & 26.07 & 5344 & 61.9 \\
\hline 5063324.2 & 1478 & 106800 & 80.28 & 400 & 32.43 & 5344 & 47.4 \\
\hline 5127007.1 & 1478 & 133500 & 100.4 & 500 & 38.79 & 5344 & 38.4 \\
\hline 5170359.8 & 1478 & 160200 & 120.4 & 600 & 45.14 & 5344 & 32.3 \\
\hline 5201777.6 & 1478 & 186900 & 140.5 & 700 & 51.5 & 5344 & 27.8 \\
\hline 5225592.7 & 1478 & 213600 & 160.6 & 800 & 57.86 & 5344 & 24.5 \\
\hline 5244266.9 & 1478 & 240300 & 180.6 & 900 & 64.21 & 5344 & 21.8 \\
\hline 5259302.5 & 1478 & 267000 & 200.7 & 1000 & 70.57 & 5344 & 19.7 \\
\hline 5271668.7 & 1478 & 293700 & 220.8 & 1100 & 76.93 & 5344 & 17.9 \\
\hline 5282018.4 & 1478 & 320400 & 240.8 & 1200 & 83.29 & 5344 & 16.5 \\
\hline 5290807.6 & 1478 & 347100 & 260.9 & 1300 & 89.64 & 5344 & 15.2 \\
\hline 5298364.6 & 1478 & 373800 & 281.0 & 1400 & 96.0 & 5344 & 14.2 \\
\hline 5304931.4 & 1478 & 400500 & 301.1 & 1500 & 102.4 & 5344 & 13.2 \\
\hline
\end{tabular}


Table 2 shows the results of calculations of the annual productivity of the MCRCC complex at different block lengths according to the 2 nd option of the technological scheme.

Table 2. Calculation results of the MCRCC complex when using the technological scheme for the development of rocks with the end arrangement of MCRCC with an increased width of the working platform.

\begin{tabular}{|c|c|c|c|c|c|c|c|}
\hline $\begin{array}{c}Q^{4} \text { COM, } \\
\mathrm{m}^{3} / \text { year }\end{array}$ & $\begin{array}{c}Q^{h}{ }_{\text {oper, }} \\
\mathrm{m}^{3} / \mathrm{h}\end{array}$ & $\begin{array}{c}V_{\text {BLOCK, }} \\
\mathrm{m}^{3}\end{array}$ & $\begin{array}{c}T_{\text {CYCLE, }} \\
\mathrm{h}\end{array}$ & $\begin{array}{c}L_{\text {BLOCK }} \\
\mathrm{m}\end{array}$ & $\begin{array}{c}\text { TD.S.M., } \\
\mathrm{h}\end{array}$ & $T_{A}, \mathrm{~h}$ & $N^{\mathrm{l}}{ }_{\text {CYCLE }}$ \\
\hline 4917382.9 & 1478 & 106800 & 83.63 & 200 & 32.43 & 5344 & 46.04 \\
\hline 5018275.7 & 1478 & 160200 & 125.4 & 300 & 45.14 & 5344 & 31.33 \\
\hline 5070290.8 & 1478 & 213600 & 167.3 & 400 & 57.86 & 5344 & 23.74 \\
\hline 5102020.6 & 1478 & 267000 & 209.1 & 500 & 70,57 & 5344 & 19.11 \\
\hline 5123395.4 & 1478 & 320400 & 250.9 & 600 & 83.29 & 5344 & 15.99 \\
\hline 5138773.1 & 1478 & 373800 & 292.7 & 700 & 96.0 & 5344 & 13.75 \\
\hline 5150367.0 & 1478 & 427200 & 334.5 & 800 & 108.7 & 5344 & 12.06 \\
\hline 5159420.8 & 1478 & 480600 & 376.3 & 900 & 121.4 & 5344 & 10.74 \\
\hline 5166686.8 & 1478 & 534000 & 418.1 & 1000 & 134.1 & 5344 & 9.68 \\
\hline 5172646.9 & 1478 & 587400 & 460.0 & 1100 & 146.9 & 5344 & 8.81 \\
\hline 5177624.2 & 1478 & 640800 & 501.8 & 1200 & 159.6 & 5344 & 8.08 \\
\hline 5181843.2 & 1478 & 694200 & 543.6 & 1300 & 172.3 & 5344 & 7.46 \\
\hline 5185465.0 & 1478 & 747600 & 585.4 & 1400 & 185.0 & 5344 & 6.94 \\
\hline 5188608.0 & 1478 & 801000 & 627.2 & 1500 & 197.7 & 5344 & 6.48 \\
\hline
\end{tabular}

Table 3 shows the results of calculations of the MCRCC complex when developing benches according to the technological scheme according to the 3-option.

Table 3. Calculation results of the MCRCC complex during the development of benches according to the technological scheme for working off the benches by longitudinal approaches by the MCRCC complex with a lateral location of the downhole conveyor and the presence of a mobile interstart loading crane with sequential mining operations at 3 horizons.

\begin{tabular}{|c|c|c|c|c|c|c|c|}
\hline $\begin{array}{c}Q^{4} \text { COM, } \\
\mathrm{m}^{3} / \text { year }\end{array}$ & $\begin{array}{c}Q^{h}{ }_{\text {oper, }} \\
\mathrm{m}^{3} / \mathrm{h}\end{array}$ & $\begin{array}{c}V_{\text {BLOCK, }} \\
\mathrm{m}^{3}\end{array}$ & $\begin{array}{c}T_{C Y C L E,}, \\
\mathrm{~h}\end{array}$ & $\begin{array}{c}L_{B L O C K} \\
\mathrm{~m}\end{array}$ & $\begin{array}{c}\text { TD.S.M., } \\
\mathrm{h}\end{array}$ & $T_{A}, \mathrm{~h}$ & $N^{1}{ }_{C Y C L E}$ \\
\hline 3441427.8 & 1478 & 156600 & 223.73 & 200 & 19.43 & 5344 & 21.98 \\
\hline 4034255.7 & 1478 & 234900 & 285.50 & 300 & 25.64 & 5344 & 17.17 \\
\hline 4414479.6 & 1478 & 313200 & 347.26 & 400 & 31.86 & 5344 & 14.09 \\
\hline 4679078.2 & 1478 & 391500 & 409.03 & 500 & 38.07 & 5344 & 11.95 \\
\hline 4873832.7 & 1478 & 469800 & 470.80 & 600 & 44.29 & 5344 & 10.37 \\
\hline 5023173.1 & 1478 & 548100 & 532.56 & 700 & 50.5 & 5344 & 9.165 \\
\hline 5141325.6 & 1478 & 626400 & 594.33 & 800 & 56.71 & 5344 & 8.208 \\
\hline 5237136.4 & 1478 & 704700 & 656.10 & 900 & 62.93 & 5344 & 7.432 \\
\hline 5316394.9 & 1478 & 783000 & 717.86 & 1000 & 69.14 & 5344 & 6.79 \\
\hline 5383049.6 & 1478 & 861300 & 779.63 & 1100 & 75.36 & 5344 & 6.25 \\
\hline 5439885.4 & 1478 & 939600 & 841.40 & 1200 & 81.57 & 5344 & 5.79 \\
\hline 5488923.1 & 1478 & 1017900 & 903.16 & 1300 & 87.79 & 5344 & 5.392 \\
\hline 5531664.6 & 1478 & 1096200 & 964.93 & 1400 & 94.0 & 5344 & 5.046 \\
\hline 5569249.3 & 1478 & 1174500 & 1026.70 & 1500 & 100.2 & 5344 & 4.742 \\
\hline
\end{tabular}

Fig. 3 shows the dependence of the annual capacity of the MCRCC complex on the length of the block when comparing three options of technological schemes: 
1-option - a flow chart of the development of rocks with the end-face arrangement of the MCRCC using a single-bucket excavator and conveyor transport;

2-option - a technological scheme for the development of rocks with an end arrangement of MCRCC and an increased width of the working platform for conveyor transport;

3-option - a technological scheme for working out benches with longitudinal runs by the MCRCC complex with a lateral location of the downhole conveyor and the presence of a mobile interstart- reloader with sequential mining operations at 3 horizons.

Graphic dependence in Fig. 3 shows that in all three variants of technological schemes with an increase in the length of the block from 200 to $1800 \mathrm{~m}$, the annual productivity of the system increases from 3500000 to $5800000 \mathrm{~m}^{3} /$ year. The graph shows that the system performance in the first and second variants have almost the same value. In the second version of the technological scheme, with an increase in the length of the block from 500 $\mathrm{m}$, the system performance is significantly reduced compared to the first version. In the third version of the technological scheme, the system performance is even faster with a small block length, but with an increase in the length of the block from $700 \mathrm{~m}$ it rapidly increases. The low performance of the system with a block length of up to $700 \mathrm{~m}$ can be explained by the fact that in the third version of the technological scheme, the number of idle transfers of the complex is larger compared to the first and second options.

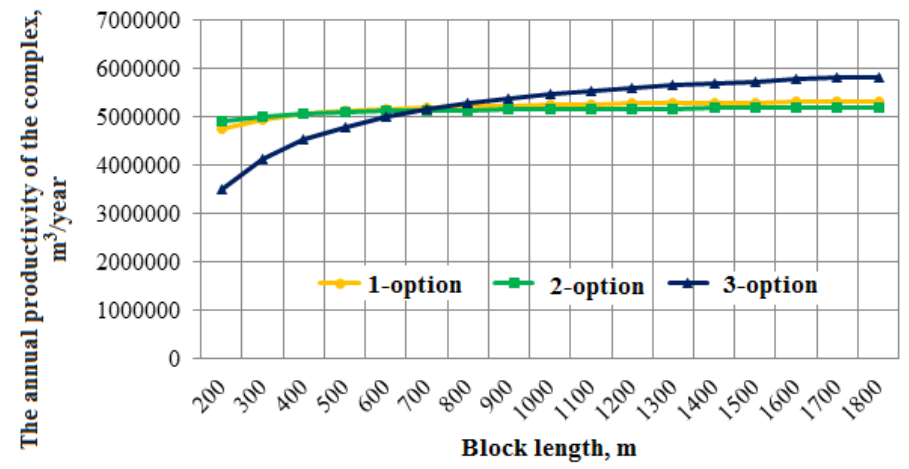

Fig. 3. Dependence of the annual productivity of the MCRCC complex on the length of the block and a comparison of three variants of technological schemes.

Thus, a methodology has been developed for determining the working time and annual productivity of the MCRCC complex by comparing three variants of technological schemes and the dependence of the annual productivity of the MCRCC complex on the block length is established.

Comparison of the three options of technological schemes, given above, showed that it is necessary to develop a fundamentally new technological scheme of central heating systems with MCRCC, which provides high system performance and low time spent on idling.

To reduce the time for idle shifting of the complex and reduce the number of exit ledges, a new technological scheme for the development of overburden ledges with the use of central heating systems with MCRCC is recommended (Fig. 4).

We have developed a new technological scheme (4-option). According to this technological scheme, the MCRCC system works on two horizons. In this case, the downhole conveyor is installed on the upper ledge. Excavator-mobile crushing-reloadingconveyor complexes first the lower ledge, and then the upper one with two runs. After that, the downhole conveyor moves along the front of the excavator [12]. 


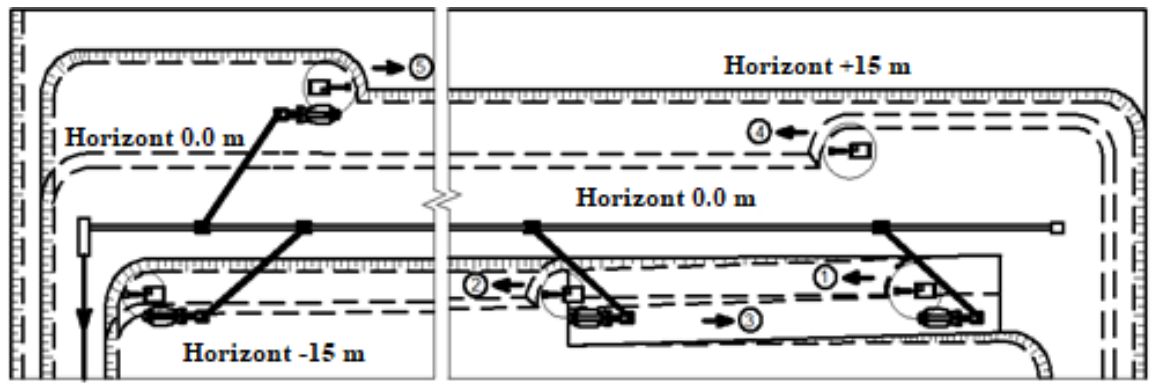

Fig. 4. The technological scheme of working out the benches with longitudinal runs by the MCRCC complex with a lateral location of the downhole conveyor and the presence of a mobile interstage reloader with sequential mining operations at two horizons.

According to this technological scheme, the MCRCC system works on two horizons. In this case, the downhole conveyor is installed on the upper ledge. Excavator-mobile crusher an interstage reloader works first on the lower ledge, and then on the upper ledge with two runs. After that, the downhole conveyor moves along the front of the excavator. Technological processes during mining operations on the exit ledge using MCRCC are shown in Table 4.

Table 4. Technological processes of mining at the exit ledge using MCRCC.

\begin{tabular}{|c|c|c|}
\hline $\begin{array}{l}\text { Process } \\
\text { number }\end{array}$ & Process name & Process brief \\
\hline 1 & $\begin{array}{l}\text { Development of the first inclined exit ledge with the descent to the } \\
\text { lower horizon }\end{array}$ & $R_{E L(1)}$ \\
\hline 2 & Development of the left flank of the main lower ledge & $R_{M L(1 L)}$ \\
\hline 3 & $\begin{array}{l}\text { U-turn and reverse movement of the complex on the left flank of the } \\
\text { lower ledge }\end{array}$ & $D_{T}+D_{M L(1 L)}$ \\
\hline 4 & Development of a second inclined exit ledge & $R_{E L(2)}$ \\
\hline 5 & $\begin{array}{l}\text { U-turn and reverse movement of the complex along the right flank } \\
\text { of the lower ledge }\end{array}$ & $D_{T}+D_{M L(1 R)}$ \\
\hline 6 & $\begin{array}{l}\text { Moving the complex along the first inclined exit ledge to the upper } \\
\text { horizon }\end{array}$ & $D_{E L(1)}$ \\
\hline 7 & Moving the complex to its starting position on the upper ledge & $D_{S P(2)}$ \\
\hline 8 & Development of the first entry of the upper ledge & $R_{M L(1 \mathrm{E})}$ \\
\hline 9 & Development of the second entry of the upper ledge & $R_{M L(2 \mathrm{E})}$ \\
\hline 10 & Movement of the complex by turning to the first starting position & $D_{S P(1)}$ \\
\hline 11 & Downhole conveyor movement & $D_{C}$ \\
\hline
\end{tabular}

According to the Table 1, combining the relevant processes, we determine the full cycle of MCRCC in the following form [6]:

$$
\begin{aligned}
& 1 C Y C L E=\left[R_{E L(1)}+R_{E L(2)}\right]+\left[R_{M L(1 L)}+R_{M L(1 E)}+R_{M L(2 E)}\right]+ \\
+ & {\left[D_{T}+D_{M L(1 L)}+D_{T}+D_{M L(1 R)}+D_{E L(1)}+D_{S P(2)}+D_{S P(1)}+D_{C}\right]=} \\
= & 2 R_{E L}+R_{M L(1 L)}+2 R_{M L(2)}+2 D_{T}+D_{M L(1)}+D_{E L(1)}+2 D_{S P}+D_{C} .
\end{aligned}
$$

The time of one cycle of working out of two benches with the use of MCRCC is [6]:

$T_{C Y C L E}=2 T_{R . E L}+T_{R . M L(1 L)}+2 T_{R . M L(2)}+2 T_{D . T}+T_{D . M L(1)}+T_{D . E L(1)}+2 T_{D . S P}+T_{D . C}, \mathrm{~h}$. 
Table 5 shows the results of calculations of the MCRCC complex when developing two benches according to the recommended technological scheme for different block lengths.

Table 5. The results of calculations of the MCRCC complex when developing two benches according to the technological scheme for different block lengths.

\begin{tabular}{|c|c|c|c|c|c|c|c|}
\hline $\begin{array}{c}Q^{4} \text { COM, } \\
\mathrm{m}^{3} / \text { year }\end{array}$ & $\begin{array}{c}Q_{\text {oper, }}^{h} \\
\mathrm{~m}^{3} / \mathrm{h}\end{array}$ & $\begin{array}{c}V_{\text {BLOCK, }} \\
\mathrm{m}^{3}\end{array}$ & $\begin{array}{c}T_{\text {CYCLE, }} \\
\mathrm{h}\end{array}$ & $\begin{array}{c}L_{B L O C K}, \\
\mathrm{~m}\end{array}$ & $\begin{array}{c}\text { TD.S.M., } \\
\mathrm{h}\end{array}$ & $T_{A}, \mathrm{~h}$ & $N^{\mathrm{l}}{ }_{\text {CYCLE }}$ \\
\hline 4443906.3 & 1478 & 160200 & 172.9 & 200 & 19.71 & 5344 & 27.74 \\
\hline 4938030.1 & 1478 & 240300 & 234.0 & 300 & 26.07 & 5344 & 20.55 \\
\hline 5228724.6 & 1478 & 320400 & 295.0 & 400 & 32.43 & 5344 & 16.32 \\
\hline 5420171.0 & 1478 & 400500 & 356.1 & 500 & 38.79 & 5344 & 13.53 \\
\hline 5555785.3 & 1478 & 480600 & 417.1 & 600 & 45.14 & 5344 & 11.56 \\
\hline 5656883.1 & 1478 & 560700 & 478.1 & 700 & 51.5 & 5344 & 10.09 \\
\hline 5735154.5 & 1478 & 640800 & 539.2 & 800 & 57.86 & 5344 & 8.95 \\
\hline 5797546.0 & 1478 & 720900 & 600.2 & 900 & 64.21 & 5344 & 8.042 \\
\hline 5848445.1 & 1478 & 801000 & 661.3 & 1000 & 70.57 & 5344 & 7.301 \\
\hline 5890759.4 & 1478 & 881100 & 722.3 & 1100 & 76.93 & 5344 & 6.686 \\
\hline 5926492.0 & 1478 & 961200 & 783.4 & 1200 & 83.29 & 5344 & 6.166 \\
\hline 5957067.5 & 1478 & 1041300 & 844.4 & 1300 & 89.64 & 5344 & 5.721 \\
\hline 5983527.3 & 1478 & 1121400 & 905.5 & 1400 & 96.0 & 5344 & 5.336 \\
\hline 6006650.0 & 1478 & 1201500 & 966.5 & 1500 & 102.4 & 5344 & 4,999 \\
\hline
\end{tabular}

The results show that the performance of the MCRCC complex increases with increasing block length. This is due to a decrease in the number of cycles during the work period during the year.

Studies have also found that the productivity of the MCRCC complex increases with a decrease in the specific time for moving the downhole conveyor during the working cycle.

As a result of the calculations of the MCRCC complex during the development of two benches with different block lengths, the dependence of the annual capacity of the MCRCC complex on the block length was established (Fig. 5).

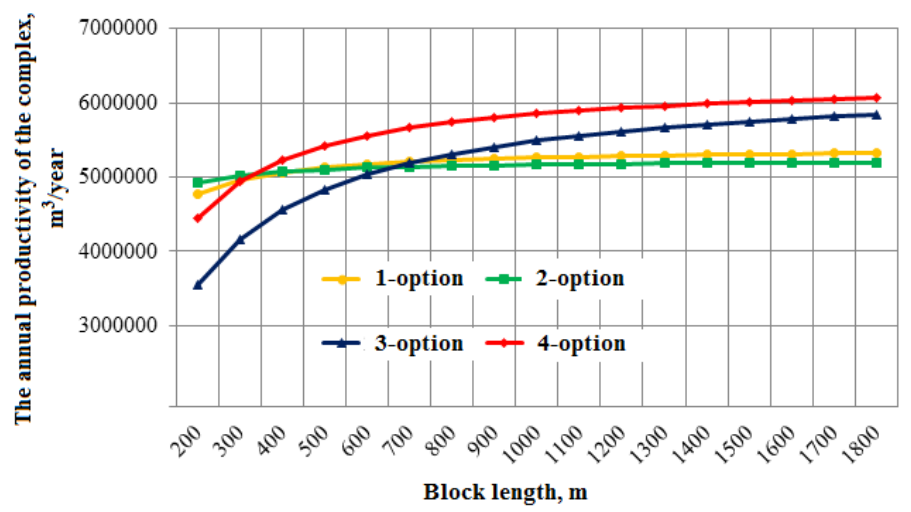

Fig. 5. The dependence of the annual productivity of the MCRCC complex on the length of the block and its comparison with the previous three variants of technological schemes.

Comparison of the new technological scheme for working out benches with longitudinal runs by the MCRCC complex with a lateral location of the downhole conveyor and the presence of a mobile interstage loading crane with sequential mining operations at two horizons showed its high productivity with an increase in the length of the block. Compared 
to the third technological scheme, idle shifts of the complex are reduced by $33 \%$, travel time on the exit ledge - by $50 \%$, and productivity of the entire complex is increased by $20 \%$. At the same time, technological indicators are the best in comparison with the three previous technological schemes.

\section{Conclusions}

The novelty of this technological scheme is the movement of the complex following the movement of the excavator in the face and thereby ensuring the flexibility and mobility of the entire mining and transport system. In combination with continuously operating conveyors, a mobile crushing complex allows you to abandon the necessary for an alternative excavator-motor transport scheme and a fleet of heavy-duty dump trucks. In addition to reducing the cost of mining, the development technology based on the new fully mobile crushing system also provides a significant reduction in emissions of exhaust gases into the surrounding atmosphere.

Thus, the recommended process flow diagram for overburden development using mobile crushing plants ensures the dynamic development of mining operations along the front and depth with high technical and economic indicators of mining.

\section{References}

1. Shpanskiy, O.V. \&. Buyanov Yu.D. (1996). Texnologiya i kompleksnaya mekhanizatsiya dobychi nerudnogo syr'ya dlya proizvodstva stroitelnykh materialov. Moskva: Nedra, 462.

2. Faul, A.A. (2012). Opredelenie parametrov i pokazateley otkrytoy razrabotki mestorozhdeniy nerudnykh stroitelnykh materialov $s$ ispolzovaniem mobilnykh drobilnykh kompleksov. $\mathrm{PhD}$ Thesis. Sankt-Peterburg, Russia.

3. Anisimov, O.A. (2015). Tekhnologiya stroitel'stva $i$ razrabotki glubokikh kar'erov. Dnipropetrovsk: Natsionalnyi hirnychyi universitet, 266.

4. Annakulov, T.J. (2015). Sovershenstvovanie tsiklichno-potochnoy tekhnologii razrabotki vskryshnykh porod $\mathrm{v}$ razreze Angrenskiy s primeneniem mobilnykh kompleksov. European Applied Sciences, (6), 58-60.

5. Moldabekov, B.K. (2014 Osobennosti primeneniya tsiklichno-potochnoy tekhnologii v usloviyakh kar'era "Aktogay". Vestnik Kazakhskogo Natsional'njgo Tekhnicheskogo Universiteta, (1), 173-178.

6. Ulrix, M., \&Yurgen, K., Pashko, P.B. (2009). Polnost'yu mobilnyy drobilnyy kompleks na gusenichnom khodu dlya krupnykh kar'erov i razrezov. Ugol', (4), 28-31.

7. Annakulov, T.J. (2019). Intensifikatsiya tsiklichno-potochnoy tekhnologii s ispol'zovaniem mobilnykh kompleksov na ugol'nykh mestorozhdeniyakh. PhD Thesis. Navoi, Kazakhstan.

8. Vremennye metodiki rascheta osnovnykh parametrov dobychnykh rabot na ugol'nykh razrezakh. (1979). Moskva: Ministerstvo ugol'noy promyshlennosti SSSR.

9. Nasirov, U.F., Zairov, Sh.Sh., \& Annakulov, T.J. (2019). Primenenie skhem tsiklichno-potochnoy tekhnologii s peredvizhnymi i mobil'nymi drobil'no-peregruzochnymi kompleksami na otkrytykh gornykh rabotakh. Gornyy Vestnik Uzbekistana, (2), 36-39.

10. Zairov, Sh.Sh., Annakulov, T.J., Kuvondikov, O.A., \& Sharipov, L.O. (2019). Raschet tekhnologicheskikh parametrov komplektov oborudovaniy mobil'nykh drobil'no-peregruzochnokonveernykh kompleksov. Gornyy Vestnik Uzbekistana, (3), 29-34.

11. Annakulov, T.J., Zairov, Sh.Sh., \& Kuvandikov, O.A. (2019). Justification, selection and calculation of technological parameters of equipment kits of mobile crushing-reloading-conveyor complexes. International Journal of Advanced Research in Science, Engineering and Technology, $6(2), 8072-8079$. 
12. Annakulov, T.J. (2019). Razrabotka tekhnologicheskikh skhem otkrytoy razrabotki mestorozhdeniy s ispolzovaniem mobilnykh kompleksov. In XXIV Mezhdunarodnaya NauchnoPrakticheskaya Konferentsiya "Innovatsiya-2019" (pp. 192-194). Tashkent, Kazakhstan: Tashkentskiy gosudarsnvehhyy tekhnicheskiy universitet.

13. Mirsaidov, G.M., Annakulov, T.J., Raimberdiev, S.U., \& A.A. Abdullaev. (2019). Opredelenie optimalnoy shiriny zakhodki ekskavatora pri primenenii mobilnykh kompleksov v usloviyakh razrabotki vskryshnykh ustupov razreza "Angrenskiy". In LXI Mezhdunarodnye Nauchnye Chteniya (pamyati A.N. Kolmogorova). Moskva, Russia: Yevropeyskiy fond innovatsionnogo razvitiya. 